This item was submitted to Loughborough's Research Repository by the author.

Items in Figshare are protected by copyright, with all rights reserved, unless otherwise indicated.

\title{
Working, but not for a living: a longitudinal study on the psychological consequences of economic vulnerability among German employees
}

\section{PLEASE CITE THE PUBLISHED VERSION}

https://doi.org/10.1080/1359432X.2020.1843533

\section{PUBLISHER}

Taylor \& Francis (Routledge)

\section{VERSION}

AM (Accepted Manuscript)

\section{PUBLISHER STATEMENT}

This is an Accepted Manuscript of an article published by Taylor \& Francis in European Journal of Work and Organizational Psychology on 23 Nov 2020, available online: http://www.tandfonline.com/10.1080/1359432X.2020.1843533.

\section{LICENCE}

CC BY-NC-ND 4.0

\section{REPOSITORY RECORD}

Klug, Katharina, Eva Selenko, and Jean-Yves Gerlitz. 2020. "Working, but Not for a Living: A Longitudinal Study on the Psychological Consequences of Economic Vulnerability Among German Employees". Loughborough University. https://hdl.handle.net/2134/13160117.v1. 
Working, but not for a living: A longitudinal study on the psychological consequences of economic vulnerability among German employees

Katharina Klug, Department of Work, Organizational and Economic Psychology, Helmut Schmidt University Hamburg, Germany

Eva Selenko, School of Business and Economics, Loughborough University, UK

Jean-Yves Gerlitz, Collaborative Research Centre 1342 "Global Dynamics of Social Policy”, University of Bremen, Germany

Author note:

Correspondence concerning this article should be addressed to Katharina Klug, Department of Work, Organizational and Economic Psychology, Helmut Schmidt University Hamburg, Holstenhofweg 85, 22043 Hamburg, Germany Email: klug@hsu-hh.de 
Total word count: 14397

\title{
Working, but not for a living: A longitudinal study on the psychological consequences of economic vulnerability among German employees
}

\begin{abstract}
Despite the rise of in-work poverty across Europe, the psychological consequences of individual economic vulnerability are still rather unknown. Drawing on both objective and subjective conceptualizations of economic vulnerability, we investigate the effects of individual low labour income and perceived financial strain on mental well-being. We argue that economic vulnerability restricts workers' agency and propose sense of control as a mediator in the relationship between economic vulnerability and mental well-being irrespective of the household's financial situation. Multilevel analyses across 19 years based on a sample of $\mathrm{N}=7,107$ employed adults from the German Socio-economic Panel (SOEP) demonstrated that a) persons reporting low income and higher financial strain showed lower health and life satisfaction, and b) intra-individual changes in income and financial strain were associated with corresponding changes in mental health and life satisfaction, respectively. These relationships were mediated by sense of control, both on the between- and the within-person level. The findings emphasize the importance of individual income and financial strain for mental well-being, and underline sense of control as an important psychological mechanism explaining individual consequences of economic vulnerability. Keywords: economic vulnerability, low income, financial strain, sense of control, mental health, in-work poverty
\end{abstract}




\section{Introduction}

Work and regular employment are often regarded as the go-to strategy to help people out of poverty by governments and policy makers. For an increasing number of people however, this strategy does not work out (Bourquin et al., 2019). Rather, they find themselves in badly paid, precarious jobs that lead to deprived living situations, where people cannot afford to eat the meals they want, heat their homes to feel comfortable, go on holidays or pay for their bills and necessities as required (Richards \& Sang, 2019). In other words, for an increasing number of people work does not pay for a decent living any more. They encounter a situation of in-work poverty, of earning at the risk of poverty despite working most of the time (Eurofound, 2017). The disconcerting news is - this phenomenon is on the rise.

Economic data on working households across Europe shows that low-paid work is increasing (Salverda, 2018) and in-work poverty rises even faster than employment rates (Peña-Casas et al., 2019).

This gives reason to be concerned, as the material and social costs of in-work poverty are devastating and well-known (e.g., Giuntoli et al., 2015; Heflin et al., 2011). Furthermore, there is strong evidence that economic vulnerability and financial strain (i.e., subjective worries related to one's finances) are correlated with poor mental health (APA, 2017; Eurofound, 2017; Lund et al., 2010). But in contrast to poverty in general, few studies address the working poor (see Pförtner \& Schmidt-Catran, 2017; Vetter et al., 2006 for exceptions), and longitudinal evidence on economic vulnerability among the employed is sparse. As a consequence, the psychological mechanisms underlying health effects of different kinds of economic vulnerability are not well understood (Burns, 2015; Sinclair \& Cheung, 2016). Considering financial pressures and fluctuations in earnings as a source of stress becomes ever more pressing as workers around the globe have to cope with reductions in working hours, job and income loss as a result of the COVID-19 pandemic (ILO, 2020a). As of April 
2020, over a third of Europeans (38\%) expected their financial situation to deteriorate, whereas 27\% report having no savings to buffer income losses (Eurofound, 2020).

Earning little despite having a job violates fundamental social reciprocity norms and meritocracy beliefs on which Western societies are built (Benabou \& Tirole, 2006; Lerner, 1980). The present study offers a work-psychological lens on the issue and focusses on individual economic vulnerability and its consequences. Drawing on Sen's (1999) capability approach and Lachman and Weaver's (1998) work on sense of control, income and health, we investigate objective and subjective aspects of economic vulnerability. We propose that both individual low labour income and perceived financial strain negatively affect mental health regardless of the household context, because they create economic dependence and undermine people's sense of control over their lives. Economic self-sufficiency, in contrast, signifies financial self-determination and independence from other household members or the welfare state. Sense of control is a core psychological construct essential for health and behaviour (Cheng et al., 2013; Groth et al., 2019), and an important resource at the workplace (Lu et al., 1999; $\mathrm{Ng}$ et al., 2006). It is hence likely that any effect of economic vulnerability on sense of control will have wider effects on a person's working life.

To test our assumptions, we analyze longitudinal data from a representative German household panel spanning over 19 years. Germany is an interesting case: starting from belowaverage levels, the country has witnessed the strongest growth of in-work poverty in the EU28 and the rate has doubled between 2005 and 2015 (Hanesch, 2019). Approaching the EU-28 median, $9 \%$ of the German workforce - almost four million workers - were estimated to be at risk of in-work poverty in 2017 (Hanesch, 2019). Conversely, more than 30\% of the poor were classified as working poor in 2018 (Pieper et al., 2019). Although these numbers refer to workers' household poverty, the fact that low-wage and non-standard jobs are important drivers of in-work poverty (Crettaz, 2013; Goerne, 2011) warrants analyzing the psychological consequences of individual low earnings in this context. 
Focussing on a psychological explanation of individual economic vulnerability, the study contributes to an under-investigated area in work and organizational psychology in several ways (see Sinclair \& Cheung, 2016). First, by developing a link between economic vulnerability and sense of control, we contribute a much-needed theoretical angle to the understanding of economic vulnerability and its individual consequences. Given the central role of sense of control in the workplace, our findings on mental well-being can pave the way to further research into work-related outcomes such as performance, proactivity or engagement that may be affected by economic vulnerability as well ( $\mathrm{Ng}$ et al., 2006). Secondly, by considering both objective and subjective indicators of economic vulnerability, we provide a more comprehensive picture than by focusing on earnings alone (Sinclair \& Cheung, 2016; Veenhoven, 2002). Finally, we conduct a multilevel analysis to separate between-person differences in accumulated economic vulnerability from acute within-person changes over time. This allows the exploration of time-bound questions such as whether people can get accustomed to poverty or what the consequences are of a sudden drop in income. By looking at changes in the individual trajectories of economic vulnerability, sense of control and health, we add longitudinal evidence to the field to better understand the causal mechanisms in the relationship between low earnings, financial strain and well-being.

\section{Conceptualizing economic vulnerability}

Prior to understanding the psychological ramifications of economic vulnerability, it is important to specify the core concepts of this study. In this study we define economic vulnerability as the combination of both objective (low labour income) and subjective aspects (perceived financial strain). In general, a person's individual financial situation can be conceptualized in objective as well as subjective terms, and both approaches have their advantages and drawbacks: In regard to income, objective income reflects people's actual access to financial resources, but often links insufficiently to well-being, because objective measures disregard subjective needs and the perceived adequacy of one's income (Chan et al., 
2002; Ullah, 1990; Veenhoven, 2002). In turn, subjective perceptions capture people’s psychological experience of financial stress, but often conflate stress resulting from low income with other factors such as a high cost of living or debt (see Sinclair \& Cheung, 2016).

The capability approach (Sen, 1999) offers a framework to integrate different conceptualizations of economic vulnerability (Burns, 2015; Hick, 2012). It differentiates between 'functionings' (i.e., what people succeed in achieving, such as being healthy) and 'capabilities' as the real substantive freedoms people have to choose between and address different functionings, so as to lead the kind of life they have reason to value. Economic resources are not seen as ends in themselves but as means to enhance capabilities (Sen, 1999). Furthermore, Sen stresses that people differ in the extent to which they can convert the same resources into functionings depending on their life circumstances, while at the same time acknowledging low income as a crucial driver of capability deprivation (Hick, 2012; Sen, 1999). This warrants an analysis of both objective income measures and people's subjective assessments of their financial situation (see also Sinclair \& Cheung, 2016; Veenhoven, 2002). We therefore investigate both objectively low labour income and perceived financial strain in this study. Following appraisal theory (Lazarus \& Folkman, 1984), we expect both indicators to correlate and affect people's mental well-being, but subjective financial strain to carry greater weight in terms of stress. In the following, we use the term economic vulnerability as the overarching umbrella term, regarding low labour income and financial strain as objective and subjective manifestations of the concept, respectively (see also Dijkstra-Kersten et al., 2015).

\section{The objective side: Low labour income}

While there are different approaches to conceptualize low pay, we define low labour income in this study as yearly individual gross earnings below the poverty line. In the EU, the poverty line is a relative measure and conventionally refers to households, defining persons with an equivalized net household income below $60 \%$ of the population median as being at 
risk of poverty (Atkinson et al., 2002). Stemming from in-work poverty research, the measure of individual low labour income has been used to disentangle and individualize the complex concept of in-work poverty (Filandri \& Struffolino, 2019; Lohmann, 2010; Peña-Casas \& Ghailani, 2011). The term poverty refers to an unacceptable state that requires intervention (Lohmann, 2018), i.e. a standard of living so far below the common level that it equates to social exclusion. In contrast, individual low labour income, can be compensated with income by other earners in the household and does not automatically translate into poverty (Gießelmann \& Lohmann, 2008; Peña-Casas \& Ghailani, 2011). A person might have a low individual income but still enjoy a decent standard of living and not experience in-work poverty because of additional earners in the household or other resources. We thus refrain from using the term in-work poverty and speak of low labour income as an objective and more inclusive indicator of economic vulnerability.

We look at individual low labour income, because we are interested in individual consequences. In contrast to low pay which focuses on hourly wages and primarily describes a certain position a person has in the income distribution (Atkinson et al., 2002; Salverda, 2018) and the living wage which aims at wellbeing, but takes the household context (e.g. average number of earners and dependents) into consideration (Anker \& Anker, 2017), we are interested in the individual ability to afford an acceptable way of life. The poverty line is a suitable threshold as it represents the resources necessary to afford a minimum acceptable standard of living for one person (Townsend, 1979). We diverge from poverty concepts insofar as we disregard the household context and other income sources such as returns from assets and public transfers, i.e. the actual need for individual labour earnings. Instead, we refer to the feminist demand for economic independence of both genders, as also envisioned by the European Commission (2010). Consequently, we understand objective individual economic vulnerability as a lack of labour earnings necessary to support a decent life, i.e., the incapacity "to form and maintain an autonomous household" (Orloff, 1993, p. 319). We argue that this 
incapacity creates economic dependence, which - even in affluent households - restricts personal control and may impair health and well-being (Ross \& Mirowsky, 2002; Springer, 2010). Furthermore, the concept indicates the individual poverty risk in case of critical life events that suddenly deteriorate household economics such as a divorce or the death of a partner.

The measure of low labour income in this study is informed by the annual gross labour income of a person. This has several advantages: a) it captures a persistent state, unaffected by monthly fluctuations; b) it is a rather conservative measure, as taxation and social security contributions are not yet deducted; c) it reflects individual labour market outcomes, independent of the family and welfare state. In contrast to wage-based conceptualizations such as the living wage (Anker, 2006), this strategy allows capturing not only low wages, but also low work intensity and underemployment as prevalent causes of economic vulnerability (Crettaz, 2013; Gerlitz, 2018; Goerne, 2011; Halleröd et al., 2015).

\section{The subjective side: Financial strain}

The subjective perception of one's own financial situation is a complex issue, of which there still is neither a unified definition nor a singular term. Indeed, researchers use constructs such as "financial worry" (worries about the financial situation and spending habits; Garðarsdóttir \& Dittmar, 2012), “perceived material deprivation” (frequency of being unable to afford necessities or recreational activities Bjarnason \& Sigurdardottir, 2003), or "perceived financial burden" (as a result of increased spending demands; Chongpison et al., 2016), and many other terms to denote financial strain.

From a conceptual point of view, the affective (i.e., worries and negative emotions) and cognitive components (i.e., evaluations of sufficiency) of a person's perception of their low-income situation have been distinguished (e.g., Sears, 2008). Some researchers have focussed on the interplay of cognitive and affective reactions (e.g., Starrin et al., 2009), while others have kept them apart, with affective reactions being investigated more frequently than 
cognitive evaluations (Sinclair \& Cheung, 2016). In the present study we concentrate on the affective side of financial strain. We use the expression 'perceived financial strain' to denote the worries people have about their financial situation in general and capture people's affective reactions to economic vulnerability in addition to low labour income.

\section{Consequences of economic vulnerability for mental well-being}

Both dimensions of economic vulnerability, low labour income as well as perceived financial strain, are likely to have substantial effects on mental well-being. In this study, we consider overall mental health and life satisfaction as indicators of well-being (Diener et al., 1999). There is already ample empirical evidence that in general, income and financial strain are associated with mental health (Adler \& Ostrove, 1999; Lund et al., 2010; Martikainen et al., 2003) and life satisfaction (Dolan et al., 2008; Hagerty \& Veenhoven, 2003; Kahneman \& Deaton, 2010). Yet little research has been devoted specifically to economic vulnerability among employees and the mechanisms that may explain its health effects. Economic vulnerability despite being employed is different from, for example, financial hardship due to unemployment or labour-inactivity: Low labour income suggests that one of the main controls an individual has over their financial situation - namely to work for an income, does not 'work'. It thereby frustrates a person's coping attempt with economic vulnerability, it disconfirms a person's hope for future improvement and it contradicts popular cultural narratives, which propose that the world is fair and hard work will pay off (Benabou \& Tirole, 2006; Bourquin et al., 2019). In that regard, low income and financial strain among the employed may be linked to mental well-being through different mechanisms than other kinds of economic vulnerability, particularly as we argue below, with regard to perceived control.

The empirical evidence on objective economic vulnerability is less straightforward than one might think, and operationalizations vary across studies. Some studies show a clear link: For example, representative panel studies have found both household poverty and low wages to be independently associated with poor self-rated health in the German workforce 
(Pförtner et al., 2019; Pförtner \& Schmidt-Catran, 2017). Research on underemployment also suggests low labour income to be associated with impaired mental health (McKee-Ryan \& Harvey, 2011). However, there is also evidence to the contrast: Investigating in-work poverty on the household level in Switzerland, a representative cross-sectional study found selfreported material deprivation to be associated with reduced mental health, but not low income on its own (Vetter et al., 2006).

On the subjective side, perceptions of financial strain have been consistently linked to lower health and well-being (Sinclair \& Cheung, 2016). Financial strain has for example shown negative relationships with mental health (Aronsson et al., 2005; Dijkstra-Kersten et al., 2015; Selenko \& Batinic, 2011; Starrin et al., 2009), sleep quality (Hall et al., 2008), physical health (Aronsson et al., 2005; Price et al., 2002), as well as blood pressure and cortisol (Steptoe et al., 2005). Altogether though, the majority of research on perceived financial strain has been cross-sectional and seldomly addressed explaining mechanisms (Sinclair \& Cheung, 2016). Given the existing evidence, we expect economic vulnerability, both in its objective and subjective manifestations, to be associated with lower mental wellbeing. Specifically addressing within-person changes, we also expect the onset of vulnerability to induce negative consequences (among others as we argue below, a decline in sense of control) and thus to cause a deterioration in mental well-being over time:

$\mathrm{H}_{1}$ : Economic vulnerability is associated with lower mental well-being. Specifically, workers experiencing economic vulnerability show lower mental well-being than less vulnerable workers $\left(\mathrm{H}_{1 \mathrm{a}}\right)$, and within-person changes in economic vulnerability are associated with corresponding changes in mental well-being $\left(\mathrm{H}_{1 \mathrm{~b}}\right)$.

\section{Proposing an explanatory mechanism: Economic vulnerability undermines workers' sense of control}

Sen's (1999) understanding of poverty as capability deprivation (i.e., restricting people's agency) points to sense of control as an explanatory mechanism of negative health 
consequences. The same logic can be applied to individual economic vulnerability, which may not always lead to poverty and affect people's achieved functionings (e.g., standard of living in a non-poor household), but may still limit an individual's freedoms and choices by creating economic dependency (Ross, 1991; Ross \& Mirowsky, 1992; Springer, 2010). Sense of control can be defined as "the belief individuals maintain about the extent to which they can shape the course of their own social outcomes" (Kraus et al., 2009, p. 993; see also Lachman \& Weaver, 1998; Rotter, 1966). It is key to mental well-being and fundamentally undermined by economic vulnerability (Pepper \& Nettle, 2017). Sense of control has originally been understood as a learned and generalized personality variable (Rotter, 1966), but more recent experimental evidence points towards it being malleable by situational influences, especially to experiences of economic uncertainty (Mittal \& Griskevicius, 2014). In line with Lachman and Weaver (1998), we therefore propose that economic vulnerability, both its objective and subjective side, will undermine workers' sense of control over their life.

First of all, economic vulnerability objectively restricts control over how one can live one's present and future life (Carr, 2019; Pepper \& Nettle, 2017). Where economic vulnerability coincides with household poverty, it limits the opportunities a person has to live their life as they need and desire at present due to material hardships, limited opportunities for social interaction outside the private home, and discrimination (Giuntoli et al., 2015; Heflin et al., 2011). In non-poor households, economically vulnerable individuals (e.g., secondary earners) may be restricted in their agency due to economic dependency on others (Ross, 1991; Springer, 2010). Economic vulnerability can also limit people's ability to pro-actively shape their future (e.g., by investing in education) and their preparedness for unforeseen future events such as unplanned expenses or a divorce (Arber et al., 2014; Carr, 2019; Lachman \& Weaver, 1998). On the subjective side, constant worries - such as about finances - by definition reflect cognitions that people experience as uncontrollable (Kircanski et al., 2015). 
Secondly, being economically vulnerable while working violates a fundamental principle of distributive justice: that people would get the outcomes they deserve based on what they do (Lerner, 1980). Economic vulnerability can thereby shake people's belief in a just world, which consists of the conviction that the world is well-meaning and malleable (Lerner, 1980, 2003). It also undermines people's experience of contingency between their own actions and outcomes, which is at the heart of the sense of control construct (Lu et al., 1999; Rotter, 1966).

Thirdly, the employment situation and daily work environment of those affected by economic vulnerability is unlikely to foster a sense of control either. Earning below the poverty-line often results from low labour intensity (Gerlitz, 2018; Halleröd et al., 2015), that is, working part-time or irregularly, experiencing spells of unemployment or inactivity, all of which have been associated with low perceived control (O’Brien \& Feather, 1990).

Furthermore, low-wage jobs typically offer little autonomy at work (Siegrist \& Marmot, 2004) or other benefits of work (e.g. sense of purpose, social contacts, status) that are deemed beneficial for well-being (Batinic et al., 2010). Finally, the material effects of low income (e.g., nutrition, limited sleep or insufficient recovery from work) and financial strain have been linked to lowered performance, proactivity, and work engagement (Edwards et al., 2007; Lowden et al., 2010; Sonnentag, 2003). Altogether, these aspects can be expected to undermine people's experience of mastery and control at work (Siegrist \& Marmot, 2004).

Empirical evidence suggests that economic deprivation can impact a sense of control. For example, economic deprivation and low socio-economic status during childhood have been linked to a lower sense of control later in life (Culpin et al., 2015; Mittal \& Griskevicius, 2014). There is also evidence that higher income is associated with a higher sense of control among adults, both cross-sectionally (Kraus et al., 2009; Lachman \& Weaver, 1998), as well as with regard to within-person changes in income over time (Specht et al., 2013). Low personal income, subjective financial strain and fear of economic descent have all been shown 
to affect sense of control (Fritsche et al., 2017). Experimental studies suggest that deprivation complicates everyday economic decision-making, thereby depleting cognitive and behavioural control (Spears, 2011). We therefore hypothesize the following:

$\mathrm{H}_{2}$ : Economic vulnerability is associated with lower sense of control. Specifically, workers experiencing economic vulnerability show lower sense of control than less vulnerable workers $\left(\mathrm{H}_{2 \mathrm{a}}\right)$, and within-person changes in economic vulnerability are associated with corresponding changes in sense of control $\left(\mathrm{H}_{2 b}\right)$.

A low sense of control plays a key role for the development of mental health problems (Cheng et al., 2013; Groth et al., 2019). The perception that one will be able to control one's future is an essential component of the stress appraisal process (Lazarus \& Folkman, 1984). A lack of this perception and the resulting reappraisal is what causes stress. This is supported by meta-analytical evidence which shows that a perceived lack of control contributes to reports of emotional exhaustion and burnout (Alarcon et al., 2009; $\mathrm{Ng}$ et al., 2006). This strongly suggests that sense of control might be the link between economic vulnerability and negative health outcomes.

Theoretically, sense of control has been proposed as an essential psychological mechanism linking social conditions to individual mental health (e.g., Lachman \& Weaver, 1998; Ross \& Mirowsky, 2002). Empirically, there is some evidence supporting a link between economic vulnerability, sense of control and mental health, but the evidence is not unequivocal. Chou and Chi (2001) found sense of control to be a plausible influence in the relationship between perceived financial strain and well-being among elderly Hong Kong Chinese people. In a British cohort study, Culpin et al. (2015) found that economic adversity at the age of 5 was correlated with self-reported sense of control at the age of 16, which in turn predicted depression at 18 years. In contrast, in a qualitative study Palomar-Lever and Victorio-Estrada (2012) did not find an influence of sense of control on mental health among Mexicans living in extreme poverty. To the best of our knowledge, no study has yet 
investigated the within-person development of individual economic vulnerability and sense of control in relation to mental health over time. We argue that sense of control is part of the explanation why economic vulnerability impairs mental health, which leads us to the following set of hypotheses:

$\mathrm{H}_{3}$ : A higher sense of control is associated with better mental well-being. Specifically, persons with a high sense of control show better mental well-being than those with lower sense of control $\left(\mathrm{H}_{3 \mathrm{a}}\right)$, and within-person changes in sense of control are associated with corresponding changes in mental well-being $\left(\mathrm{H}_{3 b}\right)$.

$\mathrm{H}_{4}$ : Sense of control mediates the effects of economic vulnerability on mental wellbeing in terms of between-person differences $\left(\mathrm{H}_{4 a}\right)$, as well as in terms of within-person changes $\left(\mathrm{H}_{4 \mathrm{~b}}\right)$.

To sum up, we expect economic vulnerability on the individual level - in objective (low income) and subjective (perceived financial strain) terms - to have negative consequences for mental well-being. Following Sen (1999), we understand economic vulnerability as capability deprivation. We therefore argue that individual economic vulnerability restricts people's agency, either by negatively affecting living conditions or where individual vulnerability does not coincide with household poverty - by creating economic dependence. Based on this reasoning, we propose sense of control as a central mediating mechanism in the relationship between economic vulnerability and mental health.

\section{Social factors related to economic vulnerability and well-being}

Trying to identify the magnitude of the effect of low income and perceived financial strain itself is not without challenges, as these two aspects of economic vulnerability are usually intertwined with a multitude of other aspects influencing a person's capabilities (Sen, 1999). This calls for a careful consideration of the structural social and economic forces that simultaneously impact a person's risk of economic vulnerability and their well-being (Burns, 2015). From a methodological standpoint, it is important to rule out spurious relationships and 
consider these factors as control variables. At the same time, the inclusion of too many control variables runs the risk of partialling out important effects of economic vulnerability.

Following Becker et al. (2016), we thus compare unadjusted effects of low labour income and perceived financial strain with the adjusted effects after controlling for empirically justified covariates. We consider sociodemographic characteristics, structural employment conditions and the household context.

As for sociodemographics, we control for gender and age. Women tend to have lower earnings, a lower sense of control (Ross \& Mirowsky, 2002), and a higher risk of depression than men (Rosenfield \& Mouzon, 2013). Earnings, financial satisfaction, sense of control and mental health also vary with age (Specht et al., 2013; Webster et al., 2014). Additionally, we consider the region of residence due to remaining disparities in well-being and in the prevalence of low-wage jobs between the former East and West of Germany (Krause, 2019; Lampert et al., 2018).

With regard to employment conditions, we consider hours worked per week and job turnover to ensure that changes in working conditions do not conflate the changes in health and wellbeing that we hope to observe (see Siegrist \& Marmot, 2004). Additionally, we control for previous unemployment which impacts both a person's chances of finding a wellpaid job and mental health (Gangl, 2006; Paul \& Moser, 2009). As temporary jobs can be disadvantageous with regard to both wages (Gebel, 2010) and well-being (Klug et al., 2019), we control for the contract type. We also include workers' level of education and occupational status to separate health effects of low income from other, related components of socioeconomic status that can influence sense of control and health (Glymour et al., 2014; Specht et al., 2013).

With regard to the household, changes in the household composition, for example a divorce, can affect mental health directly and at the same time lead to changes in economic vulnerability (Arber et al., 2014). Last but not least, we control for household income, which 
may buffer or exacerbate negative effects of low individual income (Brülle, 2016;

Gießelmann \& Lohmann, 2008). Only by controlling for the financial situation of the household, we can carve out whether individual economic vulnerability per se has an effect on mental health.

\section{Method}

\section{Sample and procedure}

Data were drawn from the German Socio-economic panel study (SOEP), a population survey of over 30,000 individuals in 12,000 households that has been conducted annually since 1984. The SOEP provides representative panel data of income, living and working conditions for both households and individuals, as all adult household members are surveyed individually each year (Wagner et al., 2007). In addition to socio-economic data, the SOEP regularly includes measures of health and subjective well-being. Whereas life satisfaction is surveyed each year, mental health has been introduced into the SOEP in 2002 and measured bi-annually since then (Andersen et al., 2007). Sense of control has been measured approximately every five years since 1999 (Richter et al., 2017). We thus analyzed the waves 1999-2017 to cover the time frame that includes all relevant constructs.

The study population consisted of all employed persons from 18 to 64 years of age who were no longer in education or training and worked part-time or full-time. We excluded the self-employed due to unreliable income data (see Gerlitz, 2018). In order to analyze within-person changes in the dependent variables over time, respondents with at least two valid observations of sense of control, mental health and life satisfaction, respectively, were included in the analyses (Allison, 2009). A sample of $N=7,107$ respondents met these criteria.

To test for selectivity, we compared the final sample to eligible respondents who provided only one valid measurement of the dependent variables. The final sample included more women $\left(\chi^{2}(1)=19.67, p<.001 ; V=.02\right)$, older respondents $(t=-23.75, p<.001 ; d=$ 
.31 , more persons living in eastern Germany $\left(\chi^{2}(1)=169.25, p<.001 ; V=.07\right)$, more single parents $\left(\chi^{2}(1)=217.86, p<.001 ; V=.08\right)$ and more professional employees $\left(\chi^{2}(1)=83.62, p\right.$ $<.001 ; V=.05)$ with a higher level of education $\left(\chi^{2}(1)=467.07, p<.001 ; V=.11\right)$. Selected respondents also changed their jobs more often $(t=-38.60, p<.001 ; d=.51)$, had more temporary contracts $(t=-19.67, p<.001 ; d=.26)$, worked more hours $(t=-14.40, p<.001 ; d$ $=.19)$, had less unemployment experience $(t=8.75, p<.001 ; d=.12)$, and higher household incomes $(t=-29.37, p<.001 ; d=.39)$. With regard to the study variables, sample respondents had more often a low labour income $(t=-13.41, p<.001 ; d=.18)$, lower mental health $(t=$ $5.35, p<.001 ; d=.08)$ and lower life satisfaction $(t=15.60, p<.001 ; d=.21)$, but did not differ from excluded respondents in financial strain or sense of control. Effect sizes indicate that most of these differences were rather small.

Respondents in the final sample were on average 38 years old $(S D=8.17)$ at the beginning of the observation period (1999) and 50 years old $(S D=8.36)$ at the end (2017); $43 \%$ were women and between 27\% (2017) and 28\% (1999) lived in eastern Germany. Between 21\% (1999) and 30\% (2017) had a university degree, 64\% had completed vocational training and 6\% (2017) - 14\% (1999) had a lower level of education (i.e., upper secondary school or less). With regard to occupational status, $25 \%$ (2017) - 40\% (1999) were manual workers, 25\% (1999) - 28\% (2017) were routine non-manual employees and 34\% (1999) $48 \%$ (2017) professional employees. Half of the respondents (54\%) changed their job at least once during the observation period, $30 \%$ had been unemployed at some point and $22 \%$ had a temporary contract at some point. Between 9\% (1999) and 15\% (2017) lived in single households, 23\% (1999) - 37\% (2017) lived with a partner, 43\% (2017) - 60\% (1999) lived with a partner and children, 5\% were single parents and 1\% (2017) - 3\% (1999) lived in other types of households. 


\section{Measures}

Economic vulnerability. We operationalized objective individual economic vulnerability in terms of low labour income with a dichotomous variable assessing whether respondents' individual earnings were above or below the poverty line (coded $0=$ above, $1=$ below). We computed the variable from respondents' inflation-adjusted individual gross labour income reported for the year prior to the survey. We used the conventional poverty line of $60 \%$ of the median equivalized household income (see Atkinson et al., 2002) based on the inflation- and household-size adjusted net household income for each survey wave from the entire cross-sectional sample. The equivalized population median was obtained by applying the modified OECD scale and pre-calculated extrapolation factors provided by the SOEP. The poverty line represents economic resources necessary to afford a minimum acceptable standard of living for one person, i.e. the capacity to maintain an autonomous household, or respectively, individual economic independence. The measure thus neglects other sources of income as well as costs due to economic dependents and indicates a potential risk. We hereby adhered to the standards of European poverty research, although we acknowledge that every poverty line and the standard of living it represents is somewhat arbitrary.

Perceived financial strain as an indicator of subjective economic vulnerability was measured with a single item asking respondents how much they worry about their personal economic situation on a three-point scale $(1=$ very worried, $2=$ somewhat worried, $3=$ not worried at all; $M=1.87, S D_{\text {between }}=0.48, S D_{\text {within }}=0.47$ ), reverse coded so that high scores reflect high strain. The item reflects financial strain in terms of respondents' negative reactions and worries related to their financial situation (Sinclair \& Cheung, 2016). Small to moderate correlations with low labour income $(r=.12)$ and household income $(r=-.44$; see Table 1) support the item's validity (Dijkstra-Kersten et al., 2015).

Sense of control. Sense of control was measured in 1999, 2005, 2010 and 2015 with a seven-item scale developed for the SOEP (Nolte et al., 1997; see also Richter et al., 2017). 
Items reflect the two components personal mastery and perceived constraints (Lachman \& Weaver, 1998), for example "How my life goes depends on myself” or "What you achieve in life is mainly a question of luck or fate". In 1999, items were rated on a four-point scale $(1=$ strongly agree to $4=$ strongly disagree), which was changed to a seven-point scale from 2005 $(1=$ strongly disagree to $7=$ strongly agree $)$. We harmonized the scale to $1-7$ across survey waves (see Specht et al., 2013) and recoded the scores such that high values reflected a high sense of control $\left(M=4.77, S D_{\text {between }}=0.75, S D_{\text {withinn }}=0.50\right)$. The scale showed acceptable reliability ranging from $\alpha=.68$ in 2005 to $\alpha=.70$ in 2015 .

Mental well-being. Mental health was measured biannually since 2002 with the SF-12 questionnaire (Ware et al., 1996). The mental health component of the the SF-12 is a six-item scale measuring vitality, affective well-being, social and emotional functioning. Respondents rated the frequency of different experiences during the past four weeks on a 5-point scale from 1 = always to 5 = never (e.g., "How often did you feel energetic?"). The SOEP includes norm-based T-scores for the scale, ranging from 0 to 100 with a mean of 50 and standard deviation of 10 (in the sample: $M=50.13, S D_{\text {between }}=6.99, S D_{\text {within }}=6.21$ ). Higher scores indicate better mental health (Andersen et al., 2007). The scale showed good reliability ranging from $\alpha=.79$ in 2008 to $\alpha=.83$ in 2016. Life satisfaction was measured with a single item ("How satisfied are you with your life, all things considered?", rated from $0=$ absolutely dissatisfied to $10=$ absolutely satisfied). Single items measures of global life satisfaction have been shown to be as valid and reliable as multi-item scales (Cheung \& Lucas, 2014; Fisher et al., 2016; Gnambs \& Buntins, 2017).

Control variables. We included sociodemographic characteristics, structural employment conditions and the household context as control variables. Socio-demographic control variables included age, gender $(0=$ man, $1=$ woman $)$, the highest achieved level of education in three categories (dummy-coded as: vocational training $0=$ no, $1=$ yes and university degree $0=$ no, 1 = yes; reference: upper-secondary school diploma or lower), 
occupational status in three categories based on the EGP scheme (Erikson, Goldthorpe, \& Portocarero, 1979; dummy-coded as: routine non-manual employee $0=$ no, $1=$ yes and professional $0=$ no, $1=$ yes; reference: manual worker $)$, and region of residence $(0=$ formerly West Germany, 1 = East Germany). Structural employment conditions included having changed jobs in the given survey wave $(0=$ no, $1=$ yes $)$, accumulated experience of unemployment in years, contract type $(0=$ permanent, $1=$ temporary $)$ and actual hours worked per week. The household context included the household type in five categories (dummy-coded as: single household $0=$ no, $1=$ yes, couple with children $0=$ no, $1=$ yes, single parent $0=$ no, $1=$ yes and other $0=$ no, $1=$ yes; reference: couple without children), and the inflation-adjusted equivalized net household income, log-transformed (see Kahneman \& Deaton, 2010).

Table 1 shows bivariate correlations between all study variables, as well as intraclass coefficients (ICC) for continuous variables and within-person percentages for categorical variables as measures of stability. The within-person percentages indicate the average percentage of time a person is observed in a particular category throughout the study period: For example, all persons who were ever observed as having low labour income reported having a low income for an average of $22 \%$ of the time they were observed.

\section{Analyses}

We calculated multilevel regression models with random intercepts using Mplus 8 (Muthén \& Muthén, 1998-2017). Stata 13 was used for descriptive statistics. In order to separate differences between persons from changes within persons in the variables of interest, we aggregated and grand-mean centred predictors on Level 2 indicating between-person variance (i.e., deviations of person-means from the sample mean), and group-mean centred predictor variables on Level 1 indicating within-person variance (i.e., individual deviations from the person-mean in a given survey wave; Raudenbush \& Bryk, 2002). Only stable categorical variables on Level 2 were not centred (Nezlek, 2012). When descriptive statistics 
indicated a high degree of stability for control variables (ICC or within- $\%>.90$ ), these were treated as time-invariant and we included only their aggregate on the between-person level for the sake of parsimony. This was the case for region of residence, level of education and unemployment experience (see Table 1).

Missing data were handled via full-information maximum likelihood (FIML) estimation, which means that all available information from the raw data is utilized to produce estimates (Enders, 2001). By default, Mplus applies FIML to dependent variables, but not to covariates. Several covariates had missing data $(1.3 \%$ on hours per week, $0.01 \%$ on unemployment experience, $3.8 \%$ on contract type, $0.2 \%$ on job change, $0.1 \%$ on level of education, $0.5 \%$ on occupational class, $0.3 \%$ on financial strain), which is why we included their means and variances in the model estimation, so that FIML was applied to the covariates as well. As this strategy makes distributional assumptions about covariates, we used the WLSMV estimator which is recommended for combinations of different types of variables (e.g., categorical and continuous) and robust against violations of normality (Muthén \& Muthén, 1998-2017). Because of the different measurement intervals for sense of control and mental health, the only year in which sense of control and mental health were observed concurrently was 2010 , which led to a very low covariance coverage $(<.10)$. We therefore used sense of control in 1999, 2005 and 2015 to predict mental health in the next available wave, that is, in 2002, 2006 and 2016, respectively, and calculated concurrent relationships for the year 2010 .

We proceeded in the following steps to test associations of low labour income and perceived financial strain with mental health and life satisfaction, respectively: We first tested the main effects without covariates separately for low labour income (Model 1) and financial strain (Model 2). We then added the indirect effect via sense of control, again separately for low labour income (Model 3) and financial strain (Model 4). Then we added control variables and simultaneous main effects for low labour income and financial strain (Model 5), and 
finally, we added control variables, low labour income, financial strain and both indirect effects via sense of control (Model 6). The mediating effects of sense of control were calculated according to the procedures described in Preacher, Zyphur \& Zhang (2010), accounting for mediation on both on the between-person level (2-2-2 mediation) and the within-person level (1-1-1 mediation).

\section{Results}

\section{Descriptive results}

The number of observations per respondent ranged from 3 to 19 with an average of $12.81(S D=3.80)$. About a third of the respondents $(29.8 \%)$ had a low labour income at least once during the observation period. The within-percentage in Table 1 indicates that these persons had a low labour income for an average of $22.4 \%$ of the time they were observed. About two thirds of the sample (68.4\%) reported being very worried about their financial situation at least once, and Table 1 shows an ICC of .47 for financial strain, indicating that $47 \%$ of the variance in financial strain is attributable to between-person differences. The ICCs for mental health, life satisfaction and sense of control indicate that between $47 \%$ and $49 \%$ of the variance in these variables is attributable to between-person differences. Thus, there was substantial variation both between persons and within persons over time in the dependent variables, but also in the mediator and the independent variables, so that multilevel analysis was warranted.

\section{Main effects of low labour income and financial strain}

Tables 2 and 3 show the results of the multilevel analyses of mental health and life satisfaction, respectively, on low labour income, financial strain and sense of control. We report standardized regression weights, so that coefficients can be interpreted in terms of standard deviations. The level 1 and level 2 effects can be interpreted as follows: At the between-person level (level 2), persons who were usually low earning (i.e., who had a higher average score on low labour income due to more observations compared to others) reported 
lower mental health $(b=-.09, p<.001$; Model 1 in Table 2$)$ and lower life satisfaction $(b=-$ $.10, p<.001$; Model 1 in Table 3 ) than those who did usually not have low earnings. After adjusting for between-person differences in sociodemographics, employment conditions, the household context and financial strain, the effects remained significant for life satisfaction, but not for mental health (see Model 5 in Table 2 and Table 3, respectively).

At the within-person level (level 1), in years when respondents had a low labour income, they reported lower mental health scores than their personal average compared to years when their earnings were above the low-income threshold $(b=-.08 ; p<.001$; Model 1 in Table 2). This effect remained significant after adjusting for changes in sociodemographic characteristics, structural employment conditions, the household context and financial strain (see Model 5 in Table 2). As can be seen in Table 3, the same pattern emerged for life satisfaction: Respondents were less satisfied with their lives in times when they had low income $(b=-.10, p<.001$; Model 1$)$ compared to times when they had higher incomes, and this effect remained significant after adjusting for covariates (see Model 5).

Subjective financial strain showed consistent negative associations with well-being at the between-person level and the within-person level, respectively. At the between-person level, persons with higher average levels of financial strain reported lower mental health $(b=$ $-.37, p<.001$; Model 2 in Table 2$)$ and lower life satisfaction $(b=-.54, p<.001$; Model 2 in Table 3) than those with lower financial strain. At the within-person level, changes in financial strain around the personal mean were associated with corresponding changes in mental health $(b=-.09, p<.001$; Model 2 in Table 2$)$ and life satisfaction $(b=-.18, p<.001$; Model 2 in Table 3). These effects remained significant after adjusting for control variables and low labour income (Model 5 in Tables 2 and 3, respectively). To sum up, Hypothesis 1 which stated that individual economic vulnerability would be associated with lower mental well-being was fully supported with regard to within-person changes (H1b) and largely supported with regard to between-person differences (H1a), with the exception that the 
between-person effect of low labour income on mental health did not hold after adjusting for covariates.

\section{Indirect effects of sense of control}

Hypothesis 2 stated that economic vulnerability would be associated with a lower sense of control. Table 4 provides an overview of the effects of low labour income and financial strain on sense of control, as well as the indirect effects of low labour income and financial strain on mental health and life satisfaction, respectively, via sense of control (unstandardized). As can be seen in the table, respondents with a low labour income reported a lower average sense of control than those with higher incomes $(b=-.37, p<.001)$ at the between-person level, but these differences were not significant when control variables and financial strain were accounted for. At the within-person level, changes in and out of low income were associated with decreases and increases in sense of control, respectively $(b=$ $.09, p<.001)$, also after adjusting for control variables. Financial strain showed consistent negative associations with sense of control: Respondents with higher average levels of financial strain reported lower average levels of sense of control $(b=-.65, p<.001$ without covariates), and increases in financial strain were associated with decreases in sense of control ( $b=-.11, p<.001$ without covariates). These associations remained significant when low labour income and control variables were accounted for. Hypothesis 2 was largely supported, with the exception that between-person differences in low labour income (H2a) were not significant after adjusting for covariates.

As predicted in Hypothesis 3, sense of control also showed consistent positive associations with well-being both at the between-person level (H3a) and the within-person level (H3b; see Models 3 and 4 in Tables 2 and 3, respectively). The effects remained significant after adjusting for sociodemographic, employment-related and household-related control variables (see Model 6 in Table 2 and 3, respectively). 
Hypothesis 4 stated that sense of control would mediate the effects of economic vulnerability on mental well-being. The indirect effects of low labour income via sense of control, both on mental health and life satisfaction, were significant at the between-person level without covariates $(b=-1.27, p<.001$ for mental health and $b=-.24, p<.001$ for life satisfaction) but not when financial strain, sociodemographic characteristics, employment conditions and household context were accounted for. At the within-person level, indirect effects of low labour income via sense of control were significant $(b=-.12, p<.001$ for mental health and $b=-.03, p<.001$ for life satisfaction), and remained significant after adjusting for control variables. Indirect effects of financial strain on mental health and life satisfaction via sense of control were significant both at the between-person level $(b=-1.69, p$ $<.001$ for mental health and $b=-.26, p<.001$ for life satisfaction) and the within-person level ( $b=-.12, p<.001$ for mental health and $b=-.03, p<.001$ for life satisfaction), with or without control variables. Hypothesis 4 thus received full support for financial strain and for low labour income on the within-person level (H4b), and partial support for low labour income on the between-person level (H4a).

\section{Discussion}

This study set out to investigate sense of control as a psychological mechanism that could explain the negative effects of objective and subjective economic vulnerability on mental well-being. We argued that low personal income and perceived financial strain would undermine workers' agency, and that this lowered sense of control over life would mediate the negative effects of economic vulnerability on mental health and life satisfaction, respectively. The results of a 19-year-long panel study not only supported the proposed relationships - by applying a multilevel approach over a long time span, we also gained rich insights regarding the effects of chronic vulnerability experiences as well as acute reactions, that is, how economically vulnerable years compare to more prosperous years over the course of an individual's working life. By uncovering sense of control as a mediator and looking at 
chronic and acute effects, we extend previous research which has established general negative health effects of economic vulnerability (e.g., Dijkstra-Kersten et al., 2015; Pförtner et al., 2019) and address important theoretical and empirical gaps regarding the psychological mechanisms that explain the development of health reactions over time (Sinclair \& Cheung, 2016).

\section{Direct relationships between economic vulnerability and mental well-being}

In line with previous research (e.g., Dijkstra-Kersten et al., 2015; Pförtner et al., 2019), the detrimental consequences of economic vulnerability are very clear in this study. Not only can we evidence this for objectively low income, but we confirm the same effects, even stronger, for subjectively perceived financial strain. Comparing people who experienced economic vulnerability with those who did not, we found that people who had accumulated more years of low income or perceived more financial strain reported lowered mental health and life satisfaction as well as a lowered sense of control. The between-person effects of low labour income were compromised when adjusting for control variables, but the effects of perceived strain remained significant. This shows that financial strain has an important effect on mental health, independent of actual income, or other demographic or job specific variables.

The findings get even more interesting when the individual trajectories of people over time are considered: In years when people reported a lower income or perceived more financial strain, they also reported a lowered sense of control and well-being (both, mental health and life satisfaction), than in years that were more prosperous. This shows that people's well-being responds to changes in their personal income and financial worries, which supports existing research on financial strain (e.g., Steptoe et al., 2005), but stands in contrast to previous findings showing that people's general health status did not change with changes in and out of working poverty operationalized at the household level (Pförtner \& SchmidtCatran, 2017). These findings support our argument that it is vital to consider individual 
labour income and not only household level poverty, when assessing the effects of working poverty.

\section{Sense of control as an explanatory mechanism}

Most importantly, our findings provide evidence why low income and financial strain impair mental well-being: As predicted, sense of control significantly mediated the effects of individual economic vulnerability on mental well-being, that is: People with low individual income or high financial strain, respectively, reported a lower sense of control compared to people with higher income and lower financial strain. In turn, people with a lower sense of control reported more mental health problems and lower life satisfaction than people with a higher sense of control, so that average differences in mental health and life satisfaction due to low income and financial strain could partly be explained by differences in sense of control. It has to be noted though, that the between-person mediation for low income did not hold after adjusting for control variables.

Interestingly, the mediation effect could be confirmed and was even more robust on the within-person level. Irrespective of sociodemographic characteristics, employment conditions or the household context, workers felt more in control in times when their personal income was above the threshold of low earnings and they had fewer financial worries, respectively, and this increase in felt control was associated with increases in mental health and life satisfaction. Taken together, our findings clearly show that workers' mental wellbeing responds to both, changes in their personal income and financial worries. The withinperson effects can be understood as reactions to sudden changes in the personal average income level and average level of perceived financial strain, like having suddenly a prosperous year (in comparison to one's other years) or experiencing a sudden drop in income. These effects cannot be attributed to unobserved stable between-person differences (Allison, 2009), for example such as childhood adversity, which might have lasting effects on economic vulnerability and sense of control in adulthood (e.g., Culpin et al., 2015). The 
results strengthen earlier cross-sectional findings on the role of sense of control in explaining health effects of income and financial strain on mental health (Chou \& Chi, 2001; Lachman \& Weaver, 1998), and support experimental and longitudinal evidence on the responsiveness of sense of control to economic pressure and changes in income (Mittal \& Griskevicius, 2014; Specht et al., 2013). In short, financially precarious employment conditions can undermine workers' perceived control over their life, with negative consequences for their mental wellbeing.

On a broader theoretical level, this study supports sense of control as a crucial psychological mechanism underlying social disparities in occupational health (see Lachman \& Weaver, 1998; Ross \& Mirowsky, 2002). Given the importance of sense of control as a resource in the workplace (Lu et al., 1999; $\mathrm{Ng}$ et al., 2006), our findings also suggest that low earnings and perceived financial strain may further hamper employees' ability to cope with stress on the job, in addition to the stress associated with low income and financial strain.

It is important to point out that most of these relationships hold (except for between person differences in income) even after controlling for 'typical' predictors of economic vulnerability (e.g., employment conditions and education), and especially the household income. This indicates that it is the individual experience of economic vulnerability that restricts people's sense of control and negatively affects mental well-being, and not just poverty on household level. Low income on its own implies a dependency on other income (e.g. of other people or of state subsidies), which seems to contribute to the reduced sense of control (see Ross \& Mirowsky, 1992, 2002; Springer, 2010). Interestingly, while earning less than one's average had a significant effect on mental well-being and sense of control even after controlling for social context; the between-person effect of accumulated years of earning below the low-income threshold on mental well-being became non-significant, once financial strain, household income, employment conditions and demographic factors were controlled for. Apparently, while people negatively respond to decreases in their income in comparison 
to their own average income irrespective of their individual, social and work background, when it comes to group differences, it is rather these demographic and employment-related risk factors associated with chronically low earnings that explain mental health differences between different earners (see Eurofound, 2017). This suggests that acute income loss has a more detrimental effect than chronic income loss - a phenomenon that has been observed before (Ennis et al., 2000). Drawing on conservation-of-resources theory Ennis and colleagues (2000) argue that acute loss of income is more stressful than chronic poverty, as it triggers a host of further acute stressors (e.g., no longer being able to afford day-care; no longer being able to afford internet etc.). They found support for this notion in a study on inner-city women's mood and their recall of material resources over the past months. The present study solidifies these findings, by providing longitudinally tracked experiences of income loss rather than remembered experiences.

In contrast, this effect seems to be the opposite when it comes to financial strain: Whereas workers' immediate reactions to their earnings sinking below or rising above the low-income threshold were comparable in magnitude and actually more robust than the health effects of accumulated low earnings, effect sizes for financial worries do not indicate adaptation, but rather suggest that negative effects may be more severe for chronic as opposed to occasional financial strain (i.e., effects were stronger at the between-person level than at the within-person level, but significant at both). In other words, while people can adapt to chronically low earnings, they do not seem to get used to chronically worrying about financial matters. Though this is a purely descriptive finding as we did not test for differences in effect size, it is a noteworthy pattern that deserves further exploration. On a more general level, these findings deliver interesting insights into the interplay of acute and chronic resource loss and associated worries as postulated by conservation of resources theory and stress literature (Ennis et al., 2000; Hobfoll \& Lilly, 1993). Acute loss of resources seems more impactful 
than chronic loss of resources, whereas acute worries appear less straining than chronic worries.

\section{Limitations and future directions}

While the study contributes to the understanding of economic vulnerability, it is not without limitations. First, the line of enquiry in this study presumes that economic vulnerability exists in an inter-subjectively agreed-upon way and that it can be approximated by a quantitative survey method. While this justifies the testing of a cause and effect relationship in a large, multi-wave population-based study and allows us to make generalizations, we are also aware of the shortcomings to this approach. Different to more qualitative approaches, we might impose certain realities and ignore others, which limits our insight into the social reality of the situation. The quantitative survey methodology certainly also limits the participants' voice. In that regard, our enquiry needs to be understood as a puzzle piece to a wider literature, where qualitative lines of enquiry are essential to understand the lived experience and meaning of economic vulnerability (Lawthom et al., 2017; Richards \& Sang, 2019).

A second limitation concerns the analysis of secondary survey data instead of designing a survey specifically for our research question, which limited the measurement of central constructs: Life satisfaction, low income and financial strain were each assessed with single items, which might provide with an unreliable sentiment. Whereas the use of single item measures is appropriate for self-reported facts such as income (Wanous et al., 1997), and their reliability is empirically well-supported for life satisfaction (Fisher et al., 2016; Gnambs \& Buntins, 2017; Lucas \& Donnellan, 2012), this is less clear with regard to financial strain. However, the item we used provides a global measure of overall financial worries that has been successfully used in previous studies (Roth et al., 2017), in addition to clear correlations with individual and household income measures in our sample. Implementing multi-item scales (e.g. Starrin et al., 2009) in future surveys would nevertheless provide a more nuanced 
assessment of different facets of financial strain, such as difficulties in paying essential bills. Though our dichotomous low income indicator was in line with conventions in poverty research (e.g., Filandri \& Struffolino, 2019), its limited variance may explain the weak relationship with sense of control and mental well-being. That said, including both objective and subjective measures of economic vulnerability is a clear strength of this study and extends previous works (e.g., Pförtner \& Schmidt-Catran, 2017; Steptoe et al., 2005). Future studies could further explore the interrelations between objective and subjective economic vulnerability (e.g., mediation or moderation) in addition to their independent effects on wellbeing (see e.g., Roth et al., 2017).

Another limitation to point out is the timing of measurements: income was assessed retrospectively (people had to recall their income of the last year), thereby rendering this measure potentially less reliable (see Prati, 2017). While this so-called simple income method is widely applied in poverty research (Debels \& Vandecasteele, 2008), it also creates a mismatch between income (previous year) and the covariates (current year). It should also be noted that the variables of interest were recorded at different intervals across the 19 years of the data collection. This led to varying time intervals in the longitudinal prediction (between 1 to 3 years) of mental health. However, the timing of measurements is also an advantage with regard to causality, as we show that income from the previous year predicts current sense of control and life satisfaction, as well as subsequent mental health. In combination with the robust effects of within-person changes, it thus seems likely that economic vulnerability undermines sense of control and in turn mental well-being, rather than (or in addition to) trait sense of control predicting earnings (see Schnitzlein \& Stephani, 2016; Spears, 2011). Future studies could theorize more explicitly on temporal aspects in the relationship between economic vulnerability and mental well-being, such as adaptation to chronic versus occasional economic vulnerability, as it has been discussed for other economic stressors (e.g., job insecurity; Klug et al., 2020). 
Though the final sample was selective in most study variables, this was not systematic and selectivity effects were small. Thus, the likelihood of a systematic selectivity bias in our estimates is low, and the large-scale panel that is by and large representative of the German workforce remains a clear strength of the study. Finally, while we did attempt to capture the economic, private and job related context an individual is in with the inclusion of control variables, we know nothing about other variables (e.g., job quality, financial dependency, quality of the living conditions) which might have contributed to feelings of undermined control. Future research would benefit particularly from including psychosocial working conditions such as job control or stressors on the job to explore their interrelationship with economic vulnerability and/or their role in explaining effects on sense of control and wellbeing (see Siegrist \& Marmot, 2004).

Finally, the extent to which our findings generalize to other countries remains unclear. Although we can expect negative psychological consequences of economic vulnerability to be more or less universal across market economies (e.g., Cheng et al., 2013; Lund et al., 2010), the strength of relationships may differ across institutional settings and cultures: For example, risk factors for in-work poverty differ between countries (Giesselmann, 2015), and the significance of sense of control for mental health is stronger in individualist compared to collectivist societies (Cheng et al., 2013). The link between poverty and mental health seems to be stronger in countries with higher levels of income inequality (Burns, 2015) and the same may be true for individual economic vulnerability. Future studies would thus benefit from taking a comparative perspective to shed more light on institutional or cultural influences on the health effects of economic vulnerability.

\section{Conclusion}

In conclusion, there are several lessons to be learned from this study. First of all, we hope that the negative effects of economic vulnerability will be of particular interest to work psychological research. The data show that financial strain has a robust and independent 
influence on sense of control and both measures of mental well-being, even after 'typical' demographic variables were controlled for. The results also show that workers' mental health is susceptible to changes in their personal income, regardless of their household or employment context. This suggests strongly that in order to fully understand mental wellbeing at the workplace, it is crucial to include financial aspects (both objective and subjective) into the data collection. Just capturing income (which is rarely collected), education or jobrelated factors (contract type, blue collar work) as control variables may not be enough.

This study is also one of the first to show that objective as well as subjective aspects of individual economic vulnerability whilst working, are detrimental to perceived control and well-being. The within-person trajectories show that low earnings and worrying about finances will have a negative effect; independent of other personal, job or social circumstances a person finds themselves in, especially independent of gender or the household's financial situation. Particularly, any event that reduces peoples' incomes will come with serious mental health effects and will lower people's sense of control. Similarly, any increase in financial worrying is likely to increase perceptions of stress.

The practical conclusions to be drawn from this study are clear: Especially in light of the current situation where the global pandemic threatens businesses and employees' livelihoods worldwide (Eurofound, 2020; ILO, 2020a), public-health policy makers, unions and employee representatives must be extra vigilant about a potential reduction of income for workers (e.g., due to short-time work, i.e. reduction in hours in order to keep a business in operation). According to conservation-of-resources theory (e.g. Ennis et al., 2000) losing income will have a far stronger effect than any similar-sized future regain will have, hence everything should be done to prevent a loss. We especially want to highlight the need to protect women's incomes and access to employment: First, women still earn less than men in many industries, and are hence more likely to fall under the low-income threshold as a result of income loss. Particularly, single mothers will be hard hit by a loss of income, as they might 
no longer be able to afford day-care for their children or other sustenance. Second, within the household women are often the ones scaling back employment to accommodate caring responsibilities and thus particularly vulnerable to economic dependency due to low work intensity - again, this is especially relevant in light of the current crisis which exacerbates gender disparities in unpaid care work as a result of closed schools and day care facilities (Alon et al., 2020; ILO, 2020b). Furthermore, given the psychological costs of falling under the low-income threshold, additional financial support measures need to be put in place, such as the state subsidies adopted in several European countries to buffer reductions in working hours in response to economic downturns (ILO, 2020a). In addition, more help must be made available to accommodate perceived financial worries, for example through a broader offering of financial counselling services inside organizations as well as public service. Most importantly, there is a need to address the financial and social realities of low-earning workers and work towards eliminating low earnings as a cause of impaired well-being instead of focussing on treatment or altering individual workers' behaviour (Smith, 2015). Increasing incomes will not just enhance low-earning workers' personal agency, but increase the value ascribed to their labour, thus reducing social stigma and injustice in underpaid jobs (Smith, 2015). We hope that by evidencing the effects of economic vulnerability, we can deliver the required scientific evidence for setting humane financial income as well as counselling support for workers.

\section{References}

Adler, N. E., \& Ostrove, J. M. (1999). Socioeconomic status and health: What we know and what we don't. Annals of the New York Academy of Sciences, 896, 3-15.

Alarcon, G., Eschleman, K. J., \& Bowling, N. A. (2009). Relationships between personality variables and burnout: A meta-analysis. Work and Stress, 23(3), 244-263.

Allison, P. D. (2009). Fixed-effects regression models. SAGE.

Alon, T., Doepke, M., Olmstead-Rumsey, J., \& Tertilt, M. (2020). The impact of COVID-19 
on gender equality (No. 26947; NBER Working Paper Series).

Andersen, H. H., Mühlbacher, A., Nübling, M., Schupp, J., \& Wagner, G. G. (2007).

Computation of standard values for physical and mental health scale scores using the SOEP version of SF-12v2. Schmollers Jahrbuch, 127, 171-182.

Anker, R. (2006). Living wages around the world: A new methodology and internationally comparable estimates. International Labour Review, 145(4), 309-338.

Anker, R., \& Anker, M. (2017). Living Wages Around the World: Manual for Measurement. Edward Elgar.

APA. (2017). Stress in America: The State of Our Nation. In Stress in America: The State of Our Nation. American Psychological Association.

Arber, S., Fenn, K., \& Meadows, R. (2014). Subjective financial well-being, income and health inequalities in mid and later life in Britain. Social Science and Medicine, 100, 12 20.

Aronsson, G., Dallner, M., Lindh, T., \& Göransson, S. (2005). Flexible pay but fixed expenses: Personal financial strain among on-call employees. International Journal of Health Services, 35(3), 499-528.

Atkinson, T., Cantillon, B., Marlier, E., \& Nolan, B. (2002). Social Indicators: The EU and Social Inclusion. Oxford University Press.

Batinic, B., Selenko, E., Stiglbauer, B., \& Paul, K. I. (2010). Are workers in high-status jobs healthier than others? Assessing Jahoda's latent benefits of employment in two working populations. Work and Stress, 24(1), 73-87.

Becker, T. E., Atinc, G., Breaugh, J. A., Carlson, K. D., Edwards, J. R., \& Spector, P. E. (2016). Statistical control in correlational studies: 10 essential recommendations for organizational researchers. Journal of Organizational Behavior, 37(2), 157-167.

Benabou, R., \& Tirole, J. (2006). Belief in a just world and redistributive politics. The Quarterly Journal of Economics, 121(2), 699-746. 
Bjarnason, T., \& Sigurdardottir, T. J. (2003). Psychological distress during unemployment and beyond: Social support and material deprivation among youth in six northern European countries. Social Science and Medicine, 56(5), 973-985.

Bourquin, P., Cribb, J., Waters, T., \& Xu, X. (2019). Why has in-work poverty risen in Britain? (W19/12; IFS Working Papers).

Brülle, J. (2016). Demographic Trends and the Changing Ability of Households to Buffer Poverty Risks in Germany. European Sociological Review, 32(6), 766-778.

Burns, J. K. (2015). Poverty, inequality and a political economy of mental health. Epidemiology and Psychiatric Sciences, 24(2), 107-113.

Carr, S. C. (2019). Standing up for Sustainable Livelihoods: From Poverty to Prosperity. In D. O’Doherty \& T. Hodgetts (Eds.), The SAGE Handbook of Applied Social Psychology. (pp. 297-320). SAGE.

Chan, A., Ofstedal, M. B., \& Hermalin, A. I. (2002). Changes in subjective and objective measures of economic well-being and their interrelationship among the elderly in Singapore and Taiwan. Social Indicators Research, 57, : 263-300.

Cheng, C., Cheung, S. F., Chio, J. H. M., \& Chan, M. P. S. (2013). Cultural meaning of perceived control: A meta-analysis of locus of control and psychological symptoms across 18 cultural regions. Psychological Bulletin, 139(1), 152-188.

Cheung, F., \& Lucas, R. E. (2014). Assessing the validity of single-item life satisfaction measures: results from three large samples. Quality of Life Research, 23(10), 2809-2818.

Chongpison, Y., Hornbrook, M. C., Harris, R. B., Herrinton, L. J., Gerald, J. K., Grant, M., Bulkley, J. E., Wendel, C. S., \& Krouse, R. S. (2016). Self-reported depression and perceived financial burden among long-term rectal cancer survivors. Psycho-Oncology, 25(11), 1350-1356.

Chou, K. L., \& Chi, I. (2001). Financial strain and depressive symptoms in Hong Kong elderly Chinese: The moderating or mediating effect of sense of control. Aging and 
Mental Health, 5(1), 23-30.

Crettaz, E. (2013). A state-of-the-art review of working poverty in advanced economies: theoretical models, measurement issues and risk groups. Journal of European Social Policy, 23(4), 347-362.

Culpin, I., Stapinski, L., Miles, Ö. B., Araya, R., \& Joinson, C. (2015). Exposure to socioeconomic adversity in early life and risk of depression at 18 years: The mediating role of locus of control. Journal of Affective Disorders, 183, 269-278.

Debels, A., \& Vandecasteele, L. (2008). The time lag in annual household-based income measures: Assessing and correcting the bias. Review of Income and Wealth, 54(1), 7188.

Diener, E., Suh, E. M., Lucas, R. E., \& Smith, H. L. (1999). Subjective well-being: Three decades of progress. Psychological Bulletin, 125(2), 276-302.

Dijkstra-Kersten, S. M. A., Biesheuvel-Leliefeld, K. E. M., van der Wouden, J. C., Penninx, B. W. J. H., \& van Marwijk, H. W. J. (2015). Associations of financial strain and income with depressive and anxiety disorders. Journal of Epidemiology and Community Health, 69(7), 660-665.

Dolan, P., Peasgood, T., \& White, M. (2008). Do we really know what makes us happy? A review of the economic literature on the factors associated with subjective well-being. Journal of Economic Psychology, 29(1), 94-122.

Edwards, J. A., Guppy, A., \& Cockerton, T. (2007). A longitudinal study exploring the relationships between occupational stressors, non-work stressors, and work performance. Work and Stress, 21(2), 99-116.

Enders, C. K. (2001). The performance of the full information maximum likelihood estimator in multiple regression models with missing data. Educational and Psychological Measurement, 61(5), 713-740.

Ennis, N. E., Hobfoll, S. E., \& Schröder, K. E. E. (2000). Money doesn’t talk, it swears: How 
economic stress and resistance resources impact inner-city women's depressive mood. American Journal of Community Psychology, 28(2), 149-173.

Erikson, R., Goldthorpe, J. H., \& Portocarero, L. (1979). Intergenerational Class Mobility in Three Western European Societies: England, France and Sweden. The British Journal of Sociology, 30(4), 415.

Eurofound. (2017). In-work poverty in the EU. European Foundation for the Improvement of Living and Working Conditions.

Eurofound. (2020). Living, working and COVID-19: First findings - April 2020 (Issue April). European Foundation for the Improvement of Living and Working Conditions. European Commission. (2010). Strategy for equality between women and men 2010-2015.

Filandri, M., \& Struffolino, E. (2019). Individual and household in-work poverty in Europe: understanding the role of labor market characteristics. European Societies, 21(1), 130157.

Fisher, G. G., Matthews, R. A., \& Gibbons, A. M. (2016). Developing and investigating the use of single-item measures in organizational research. Journal of Occupational Health Psychology, 21(1), 3-23.

Fritsche, I., Moya, M., Bukowski, M., Jugert, P., de Lemus, S., Decker, O., Valor-Segura, I., \& Navarro-Carrillo, G. (2017). The Great Recession and group-based control: Converting personal helplessness into social class in-group trust and collective action. Journal of Social Issues, 73(1), 117-137.

Gangl, M. (2006). Scar effects of Unemployment: An Assessment of Institutional Complementarities. American Sociological Review, 71(6), 986-1013.

Garðarsdóttir, R. B., \& Dittmar, H. (2012). The relationship of materialism to debt and financial well-being: The case of Iceland's perceived prosperity. Journal of Economic Psychology, 33(3), 471-481.

Gebel, M. (2010). Early career consequences of temporary employment in Germany and the 
UK. Work, Employment and Society, 24(4), 641-660.

Gerlitz, J.-Y. (2018). Rising in-work poverty in times of activation: Changes in the distributive performance of institutions over three decades, Germany 1984-2013. Social Indicators Research, 140(3), 1109-1129.

Giesselmann, M. (2015). Differences in the patterns of in-work poverty in Germany and the UK. European Societies, 17(1), 27-46.

Gießelmann, M., \& Lohmann, H. (2008). The different roles of low-wage work in Germany: Regional, demographical and temporal variances in the poverty risk of low-paid workers. In H.-J. Andreß \& H. Lohmann (Eds.), The Working Poor in Europe: Employment, Poverty and Globalisation (pp. 96-123). Edward Elgar.

Giuntoli, G., Hughes, S., Karban, K., \& South, J. (2015). Towards a middle-range theory of mental health and well-being effects of employment transitions: Findings from a qualitative study on unemployment during the 2009-2010 economic recession. Health (United Kingdom), 19(4), 389-412.

Glymour, M., Avendano, M., \& Kawachi, I. (2014). Socio-economic status and health. In L. F. Berkman, I. Kawachi, \& M. Glymour (Eds.), Social Epidemiology (2nd ed., pp. 1762). Oxford University Press.

Gnambs, T., \& Buntins, K. (2017). The measurement of variability and change in life satisfaction. A comparison of single-item and multi-item instruments. European Journal of Psychological Assessment, 33(4), 224-238.

Goerne, A. (2011). A comparative analysis of in-work poverty in the European Union. In N Fraser, R. Gutiérrez, \& R. Peña-Casas (Eds.), Work and Welfare in Europe. Working Poverty in Europe: A Comparative Approach (pp. 15-45). Palgrave Macmillan.

Groth, N., Schnyder, N., Kaess, M., Markovic, A., Rietschel, L., Moser, S., Michel, C., Schultze-Lutter, F., \& Schmidt, S. J. (2019). Coping as a mediator between locus of control, competence beliefs, and mental health: A systematic review and structural 
equation modelling meta-analysis. Behaviour Research and Therapy, 121, 103442.

Hagerty, M. R., \& Veenhoven, R. (2003). Wealth and happiness revisited - Growing national income does go with greater happiness. Social Indicators Research, 64(1), 1-27.

Hall, M., Buysse, D. J., Nofzinger, E. A., Reynolds, C. F., Thompson, W., Mazumdar, S., \& Monk, T. H. (2008). Financial strain is a significant correlate of sleep continuity disturbances in late-life. Biological Psychology, 77(2), 217-222.

Halleröd, B., Ekbrand, H., \& Bengtsson, M. (2015). In-work poverty and labour market trajectories: Poverty risks among the working population in 22 European countries. Journal of European Social Policy, 25(5), 473-488.

Hanesch, W. (2019). ESPN Thematic Report on In-work poverty - Germany. European Commission.

Heflin, C., London, A. S., \& Scott, E. K. (2011). Mitigating Material Hardship: The Strategies Low-Income Families Employ to Reduce the Consequences of Poverty. Sociological Inquiry, 81(2), 223-246.

Hick, R. (2012). The capability approach: Insights for a new poverty focus. Journal of Social Policy, 41(2), 291-308.

Hobfoll, S. E., \& Lilly, R. S. (1993). Resource conservation as a strategy for community psychology. Journal of Community Psychology, 21(2), 128-148.

ILO. (2020a). ILO Monitor: COVID-19 and the world of work. Second edition (Issue April). International Labour Organization.

ILO. (2020b). The COVID-19 response: Getting gender equality right for a better future for women at work (Issue May). International Labour Organization.

Kahneman, D., \& Deaton, A. (2010). High income improves evaluation of life but not emotional well-being. Proceedings of the National Academy of Sciences of the United States of America, 107(38), 16489-16493.

Kircanski, K., Thompson, R. J., Sorenson, J., Sherdell, L., \& Gotlib, I. H. (2015). Rumination 
and worry in daily life: Examining the naturalistic validity of theoretical constructs. Clinical Psychological Science, 3(6), 926-939.

Klug, K., Bernhard-Oettel, C., Selenko, E., \& Sverke, M. (2020). Temporal and personoriented perspectives on job insecurity. In Handbook on the Temporal Dynamics of Organizational Behavior (pp. 91-104). Edward Elgar.

Klug, K., Drobnič, S., \& Brockmann, H. (2019). Trajectories of insecurity: Young adults' employment entry, health and well-being. Journal of Vocational Behavior, 115, 11380.

Kraus, M. W., Piff, P. K., \& Keltner, D. (2009). Social class, sense of control, and social Explanation. Journal of Personality and Social Psychology, 97(6), 992-1004.

Krause, P. (2019). 30 Jahre seit dem Mauerfall: Fortschritte und Defizite bei der Angleichung der Lebensverhältnisse in Ost- und Westdeutschland. DIW-Wochenbericht, 86(45), 827838.

Lachman, M. E., \& Weaver, S. L. (1998). The sense of control as a moderator of social class differences in health and well-being. In Journal of Personality and Social Psychology, 74(3), 763-773.

Lampert, T., Kroll, L. E., Kuntz, B., \& Hoebel, J. (2018). Gesundheitliche Ungleichheit in Deutschland und im inter nationalen Vergleich: Zeitliche Entwicklungen und Trends. Journal of Health Monitoring, 3(S1), 1-26.

Lawthom, R., Kagan, C., Burton, M., Lo, S., Mok, L., Sham, S., Baines, S., \& Greenwood, M. (2017). Partnership working as liberation psychology: Forced labor among UK Chinese migrant workers. Journal of Prevention and Intervention in the Community, 45(1), 7-18.

Lazarus, R. S., \& Folkman, S. (1984). Stress, appraisal and coping. Springer.

Lerner, M. J. (1980). The Belief in a Just World. In The Belief in a Just World (pp. 9-30). Springer US.

Lerner, M. J. (2003). The justice motive: Where social psychologists found it, how they lost 
it, and why they may not find It again. Personality and Social Psychology Review, 7(4), $388-399$.

Lohmann, H. (2010). Armut von Erwerbstätigen im europäischen Vergleich. Erwerbseinkommen und Umverteilung. Kölner Zeitschrift für Soziologie und Sozialpsychologie, 62(1), 1-30.

Lohmann, H. (2018). The concept and measurement of in-work poverty. In H. Lohmann \& I. Marx (Eds.), Handbook on In-Work Poverty (pp. 124-145). Edward Elgar.

Lowden, A., Moreno, C., Holmbäck, U., Lenneräs, M., \& Tucker, P. (2010). Eating and shift work - effects on habits, metabolism and performance. Scandinavian Journal of Work, Environment \& Health, 36(2), 150-163.

Lu, L., Wu, H.-L., \& Cooper, C. L. (1999). Perceived work stress and locus of control: A combined quantitative and qualitative approach. Research and Practice in Human Resource Management, 7(1), 1-15.

Lucas, R. E., \& Donnellan, M. B. (2012). Estimating the reliability of single-item life satisfaction measures: Results from four national panel studies. Social Indicators Research, 105(3), 323-331.

Lund, C., Breen, A., Flisher, A. J., Kakuma, R., Corrigall, J., Joska, J. A., Swartz, L., \& Patel, V. (2010). Poverty and common mental disorders in low and middle income countries: A systematic review. Social Science and Medicine, 71(3), 517-528.

Martikainen, P., Adda, J., Ferrie, J. E., Davey Smith, G., \& Marmot, M. G. (2003). Effects of income and wealth on GHQ depression and poor self rated health in white collar women and men in the Whitehall II study. Journal of Epidemiology and Community Health, 57(9), 718-723.

McKee-Ryan, F. M., \& Harvey, J. (2011). "I have a job, but . . ”: A review of underemployment. Journal of Management, 37(4), 962-996.

Mittal, C., \& Griskevicius, V. (2014). Sense of Control Under Uncertainty Depends on 
People's Childhood Environment: A Life History Theory Approach. Journal of Personality and Social Psychology, 107(4), 621-637.

Muthén, L. K., \& Muthén, B. O. (1998-2017). Mplus User’s Guide (8th ed.). Muthén \& Muthén.

Nezlek, J. B. (2012). Multilevel modeling for psychologists. In H. Cooper (Ed.), APA Handbook of Research Methods in Psychology: Vol 3. Data Analysis and Research Publication (pp. 219-241). American Psychological Association.

Ng, T. W. H., Sorensen, K. L., \& Eby, L. T. (2006). Locus of control at work: A metaanalysis. Journal of Organizational Behavior, 27, 1057-1087.

Nolte, H., Weischer, C., Wilkesmann, U., \& Tegethoff, H. G. (1997). Kontrolleinstellungen zum Leben und zur Zukunft: Auswertung eines neuen sozialpsychologischen Itemblocks im sozio-ökonomischen Panel (No. 97-06; Diskussionspapiere Aus Der Fakultät Für Sozialwissenschaft).

O'Brien, G. E., \& Feather, N. T. (1990). The relative effects of unemployment and quality of employment on the affect, work values and personal control of adolescents. Journal of Occupational Psychology, 63(2), 151-165.

Orloff, A. S. (1993). Gender and the social rights of citizenship: the comparative analysis of gender relations and welfare states. American Sociological Review, 58(3), 303-328.

Palomar-Lever, J., \& Victorio-Estrada, A. (2012). Factors that influence emotional disturbance in adults living in extreme poverty. Scandinavian Journal of Psychology, $53(2), 158-164$.

Paul, K. I., \& Moser, K. (2009). Unemployment impairs mental health: Meta-analyses. Journal of Vocational Behavior, 74(3), 264-282.

Peña-Casas, R., \& Ghailani, D. (2011). Towards Individualizing Gender In-Work Poverty Risks. In Neil Fraser, R. Gutiérrez, \& R. Peña-Casas (Eds.), Working Poverty in Europe (pp. 202-231). Palgrave Macmillan. 
Peña-Casas, R., Ghailani, D., Spasova, S., \& Vanhercke, B. (2019). In-work poverty in Europe. A study of national policies. European Commission.

Pepper, G. V., \& Nettle, D. (2017). The behavioural constellation of deprivation: Causes and consequences. Behavioral and Brain Sciences, 40.

Pförtner, T.-K., Pfaff, H., \& Hower, K. I. (2019). Trends in the association of different forms of precarious employment and self-rated health in Germany. An analysis with the German Socio-Economic Panel between 1995 and 2015. Journal of Epidemiology and Community Health, 73(11), 1002-1011.

Pförtner, T.-K., \& Schmidt-Catran, A. W. (2017). In-work poverty and self-rated health in a cohort of working Germans : A hybrid approach for decomposing within-person and between-persons estimates of in-work poverty status. American Journal of Epidemiology, 185(4), 274-282.

Pieper, J., Schneider, U., Schröder, W., \& Stilling, G. (2019). 30 Jahre Mauerfall - Ein viergeteiltes Deutschland. Der Paritätische Gesamtverband.

Prati, A. (2017). Hedonic recall bias. Why you should not ask people how much they earn. Journal of Economic Behavior and Organization, 143, 78-97.

Preacher, K. J., Zyphur, M. J., \& Zhang, Z. (2010). A general multilevel SEM framework for assessing multilevel mediation. Psychological Methods, 15(3), 209-233.

Price, R. H., Choi, J. N., \& Vinokur, A. D. (2002). Links in the chain of adversity following job loss: How financial strain and loss of personal control lead to depression, impaired functioning, and poor health. Journal of Occupational Health Psychology, 7(4), 302312.

Raudenbush, S. W., \& Bryk, A. S. (2002). Hierarchical Linear Models (2nd ed.). Sage.

Richards, J., \& Sang, K. (2019). The intersection of disability and in-work poverty in an advanced industrial nation: The lived experience of multiple disadvantage in a postfinancial crisis UK. Economic and Industrial Democracy, 40(3), 636-659. 
Richter, D., Rohrer, J., Metzing, M., Nestler, W., Weinhardt, M., \& Schupp, J. (2017). SOEP Scales Manual (updated for SOEP-Core v32.1), (No. 423; SOEP Survey Papers).

Rosenfield, S., \& Mouzon, D. (2013). Gender and mental health. In C. S. Aneshensel, J. Phelan, \& A. Biermann (Eds.), Handbook of the Sociology of Mental Health (pp. 277296). Springer.

Ross, C. E. (1991). Marriage and the sense of control. Journal of Marriage and the Family, $53(4), 831$.

Ross, C. E., \& Mirowsky, J. (1992). Households, employment, and the sense of control. Social Psychology Quarterly, 55(3), 217.

Ross, C. E., \& Mirowsky, J. (2002). Age and the gender gap in the sense of personal control. Social Psychology Quarterly, 65(2), 125.

Roth, B., Hahn, E., \& Spinath, F. M. (2017). Income inequality, life satisfaction, and economic worries. Social Psychological and Personality Science, 8(2), 133-141.

Rotter, J. B. (1966). Generalized expectancies for internal versus external control of reinforcement. In Psychological monographs, 80(1), 1-28.

Salverda, W. (2018). Low earnings and their drivers in relation to in-work poverty. In H. Lohmann \& I. Marx (Eds.), Handbook on In-Work Poverty (pp. 26-49). Edward Elgar.

Schnitzlein, D. D., \& Stephani, J. (2016). Locus of Control and low-wage mobility. Journal of Economic Psychology, 53, 164-177.

Sears, L. E. (2008). Work-related outcomes of financial stress: Relating perceived income adequacy and financial strain to job performance and worker well-being. Dissertation, Portland State University.

Selenko, E., \& Batinic, B. (2011). Beyond debt. A moderator analysis of the relationship between perceived financial strain and mental health. Social Science \& Medicine, 73, $1725-1732$.

Sen, A. (1999). Development as Freedom. Oxford University Press. 
Siegrist, J., \& Marmot, M. (2004). Health inequalities and the psychosocial environment-two scientific challenges. Social Science \& Medicine, 58(8), 1463-1473.

Sinclair, R. R., \& Cheung, J. H. (2016). Money matters: Recommendations for financial stress research in Occupational Health Psychology. Stress and Health, 32(3), 181-193.

Smith, L. (2015). Reforming the minimum wage: Toward a psychological perspective. American Psychologist, 70(6), 557-565.

Sonnentag, S. (2003). Recovery, work engagement, and proactive behavior: A new look at the interface between nonwork and work. Journal of Applied Psychology, 88(3), 518-528.

Spears, D. (2011). Economic decision-making in poverty depletes behavioral control. The B.E. Journal of Economic Analysis and Policy, 11(1), 1-42.

Specht, J., Egloff, B., \& Schmukle, S. C. (2013). Everything Under Control? The Effects of Age, Gender, and Education on Trajectories of Perceived Control in a Nationally Representative German Sample. Developmental Psychology, 49(2), 353-364.

Springer, K. W. (2010). Economic Dependence in Marriage and Husbands' Midlife Health. Gender \& Society, 24(3), 378-401.

Starrin, B., Åslund, C., \& Nilsson, K. W. (2009). Financial stress, shaming experiences and psychosocial Ill-Health: Studies into the finances-shame model. Social Indicators Research, 91(2), 283-298.

Steptoe, A., Brydon, L., \& Kunz-Ebrecht, S. (2005). Changes in financial strain over three years, ambulatory blood pressure, and cortisol responses to awakening. Psychosomatic Medicine, 67(2), 281-287.

Townsend, P. (1979). Poverty in the United Kingdom: A Survey of Household Resources and Standards of Living. Penguin books.

Ullah, P. (1990). The association between income, financial strain and psychological wellbeing among unemployed youths. Journal of Occupational Psychology, 63(4), 317-330. Veenhoven, R. (2002). Why social policy needs subjective indicators. Social Indicators 
Research, 58, 33-45.

Vetter, S., Endrass, J., Schweizer, I., Teng, H. M., Rossler, W., \& Gallo, W. T. (2006). The effects of economic deprivation on psychological well-being among the working population of Switzerland. BMC Public Health, 6, 1-10.

Wagner, G. G., Frick, J. R., \& Schupp, J. (2007). The German Socio-Economic Panel Study (SOEP) - evolution, scope and enhancements. (No. 1, SOEPpapers on Multidisciplinary Panel Data Research).

Wanous, J. P., Reichers, A. E., \& Hudy, M. J. (1997). Overall Job Satisfaction: How Good Are Single-Item Measures? Journal of Applied Psychology, 82(2), 247-252.

Webster, J. D., Westerhof, G. J., \& Bohlmeijer, E. T. (2014). Wisdom and mental health across the lifespan. Journals of Gerontology - Series B Psychological Sciences and Social Sciences, 69(2), 209-218. 
Table 1. Bivariate correlations, intraclass coefficients and within-person percentages for all study variables.

\begin{tabular}{|c|c|c|c|c|c|c|c|c|c|c|c|c|c|c|c|c|c|c|c|c|c|c|c|}
\hline & ICC & $\begin{array}{c}\text { Within } \\
\%\end{array}$ & 1 & 2 & 3 & 4 & 5 & 6 & 7 & 8 & 9 & 10 & 11 & 12 & 13 & 14 & 15 & 16 & 17 & 18 & 19 & 20 & 21 \\
\hline \multicolumn{24}{|c|}{ Sociodemographic characteristics } \\
\hline 1 Gender & & & - & & & & & & & & & & & & & & & & & & & & \\
\hline 2 Age & .79 & & .00 & - & & & & .07 & -.02 & -.01 & -.12 & -.10 & & .06 & -.19 & -.01 & -.05 & .27 & -.08 & -.08 & -.08 & .03 & -.05 \\
\hline 3 Region: East & & 94.5 & .05 & .03 & - & & & & & & & & & & & & & & & & & & \\
\hline \multicolumn{24}{|l|}{ Education } \\
\hline 4 Vocational training & & 95.0 & -.03 & -.08 & -.02 & - & & & & & & & & & & & & & & & & & \\
\hline 5 University & & 96.7 & .01 & .12 & .08 & -.86 & - & & & & & & & & & & & & & & & & \\
\hline \multicolumn{24}{|c|}{ Occupational status } \\
\hline 6 Routine non-manual & & 65.6 & .39 & .01 & .02 & .18 & -.17 & - & -.69 & -.02 & .01 & .00 & & .00 & -.01 & .01 & .00 & -.01 & .00 & .01 & -.01 & -.01 & .00 \\
\hline 7 Professional & & 74.9 & -.03 & .12 & -.05 & -.40 & .50 & -.40 & - & .02 & -.02 & -.02 & & .00 & .00 & .00 & -.01 & .03 & -.01 & -.02 & .01 & .01 & .00 \\
\hline 8 Hours per week & .71 & & -.50 & -.03 & .11 & -.09 & .13 & -.27 & .13 & - & -.05 & -.02 & & .03 & -.07 & .01 & -.01 & .09 & -.01 & -.15 & .02 & -.05 & -.01 \\
\hline 9 Job change & & 18.2 & .04 & -.32 & .04 & -.01 & .02 & .00 & -.02 & .05 & - & .25 & & -.02 & .02 & .00 & .01 & -.11 & .01 & .30 & -.03 & .01 & .01 \\
\hline 10 Contract: temporary & & 22.4 & .06 & -.16 & .06 & -.05 & .04 & -.02 & -.03 & .00 & .44 & - & & .00 & .00 & .02 & .01 & -.07 & .05 & .13 & -.03 & -.01 & -.01 \\
\hline 11 Unemployment exp. & .94 & & .05 & .02 & .11 & .05 & -.10 & .00 & -.16 & -.05 & .28 & .23 & - & & & & & & & & & & \\
\hline \multicolumn{24}{|l|}{ Household context } \\
\hline 12 Single & & 49.4 & -.01 & -.04 & -.04 & .00 & .01 & .02 & .07 & .08 & .05 & .03 & .03 & - & -.25 & -.21 & -.06 & -.07 & -.01 & -.02 & .01 & -.03 & -.05 \\
\hline 13 Couple w. children & & 71.0 & -.17 & -.04 & .01 & .01 & .00 & .02 & .08 & -.05 & -.02 & -.04 & -.07 & -.39 & - & -.25 & -.13 & -.17 & .03 & .05 & .00 & -.01 & .01 \\
\hline 14 Single parent & & 42.9 & .17 & -.01 & .00 & .02 & -.03 & .09 & -.01 & -.08 & .04 & .04 & .05 & .00 & -.19 & - & -.05 & -.12 & .03 & -.01 & -.02 & -.02 & -.03 \\
\hline $\mathbf{1 5}$ Other & & 35.5 & .02 & .02 & -.00 & .02 & -.02 & .02 & -.02 & .00 & -.02 & .01 & -.02 & -.04 & -.12 & -.01 & - & -.02 & .00 & .01 & -.01 & .00 & -.01 \\
\hline 16 Household income & .75 & & .04 & .23 & -.18 & -.29 & .40 & -.06 & .45 & .12 & -.17 & -.13 & -.28 & -.05 & -.12 & -.16 & -.02 & - & -.09 & -.20 & .06 & .03 & .03 \\
\hline \multicolumn{24}{|l|}{ Economic vulnerability } \\
\hline 17 Low labour income & & 22.4 & .29 & -.08 & .10 & .08 & -.12 & .18 & -.19 & -.37 & .23 & .16 & .25 & -.06 & .01 & .06 & -.01 & -.25 & - & .02 & -.03 & -.01 & -.02 \\
\hline 18 Financial strain & .47 & & .04 & -.08 & .14 & .18 & -.25 & .07 & -.31 & -.02 & .13 & .10 & .20 & -.04 & .03 & .07 & .01 & -.44 & .16 & - & -.10 & -.13 & -.19 \\
\hline \multicolumn{24}{|l|}{ Mental well-being } \\
\hline 19 Sense of control & .49 & & -.04 & -.05 & -.04 & -.09 & .14 & -.05 & .18 & .07 & .00 & -.02 & -.12 & -.00 & .03 & -.05 & -.03 & .21 & -.08 & -.42 & - & .17 & .16 \\
\hline 20 Mental health & .47 & & -.14 & .07 & -.06 & -.01 & .01 & -.05 & -.00 & .03 & -.07 & -.05 & -.05 & -.04 & .05 & -.05 & .01 & .08 & -.07 & -.33 & .36 & - & .31 \\
\hline 21 Life satisfaction & .49 & & -.01 & -.08 & -.15 & -.10 & .13 & -.02 & .14 & -.04 & -.07 & -.05 & -.18 & -.09 & .07 & -.07 & -.00 & .26 & -.08 & -.51 & .43 & .53 & - \\
\hline
\end{tabular}

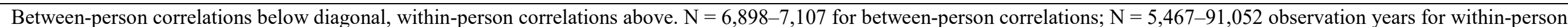

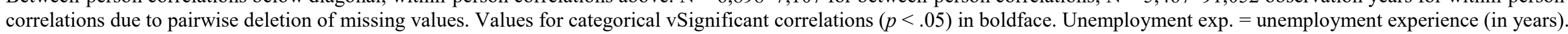
ICC = Intraclass coefficient. 
Table 2. Multilevel regression of mental health on low labour income, financial strain and sense of control (random intercept models).

\begin{tabular}{|c|c|c|c|c|c|c|}
\hline & Model 1 & Model 2 & Model 3 & Model 4 & Model 5 & Model 6 \\
\hline & $b$ & $b$ & $b$ & $b$ & $b$ & $b$ \\
\hline \multicolumn{7}{|c|}{ Level 1 predictors (within persons) } \\
\hline Low labour income & $-.08^{* *}$ & & $-.07 *$ & & $-.07 *$ & $-.06^{*}$ \\
\hline Financial strain & & $-.09 * * *$ & & $-.09 * * *$ & $-.09 * * *$ & $-.09 * * *$ \\
\hline Sense of control & & & $.10^{* * *}$ & $.09 * * *$ & & $.09 * * *$ \\
\hline \multicolumn{7}{|l|}{ Level 1 control variables } \\
\hline Age & & & & & $.02 * * *$ & $.02 * * *$ \\
\hline \multicolumn{7}{|l|}{ Occupational status } \\
\hline Routine non-manual & & & & & .00 & .00 \\
\hline Professional & & & & & .00 & .00 \\
\hline Hours per week & & & & & $-.03 * * *$ & $-.03 * * *$ \\
\hline Job change & & & & & .00 & .00 \\
\hline Temporary contract & & & & & .00 & .00 \\
\hline \multicolumn{7}{|l|}{ Household type } \\
\hline Single & & & & & $-.13^{* * *}$ & $-.14 * * *$ \\
\hline Couple with children & & & & & $-.06 * *$ & $-.07 * * *$ \\
\hline Single parent & & & & & $-.14 * * *$ & $-.14 * * *$ \\
\hline Other & & & & & -.06 & -.06 \\
\hline Household income & & & & & .01 & 00 \\
\hline \multicolumn{7}{|c|}{ Level 2 predictors (between persons) } \\
\hline Low labour income & $-.09 * * *$ & & $-.05 * * *$ & & -.02 & -.01 \\
\hline Financial strain & & $-.37 * * *$ & & $-.24 * * *$ & $-.35 * * *$ & $-.23 * * *$ \\
\hline Sense of control & & & $.41 * * *$ & $.31^{* * *}$ & & $.34 * * *$ \\
\hline \multicolumn{7}{|l|}{ Level 2 control variables } \\
\hline Gender: woman & & & & & $-.23 * * *$ & $-.27 * * *$ \\
\hline Age & & & & & $.06 * * *$ & $.09 * * *$ \\
\hline \multicolumn{7}{|l|}{ Education } \\
\hline Vocational & & & & & .01 & .01 \\
\hline Tertiary & & & & & -.02 & $-.04 * *$ \\
\hline \multicolumn{7}{|l|}{ Occupational status } \\
\hline Routine non-manual & & & & & .02 & $.03^{*}$ \\
\hline Professional & & & & & $-.06 * * *$ & $.09 *$ \\
\hline Hours per week & & & & & $-.06 * * *$ & $-.07 * * *$ \\
\hline Job change & & & & & $-.04 * *$ & $-.10 * * *$ \\
\hline Temporary contract & & & & & -.02 & $-.03 * *$ \\
\hline Unemployment exp. & & & & & -.02 & .01 \\
\hline \multicolumn{7}{|l|}{ Household type } \\
\hline Single & & & & & $-.03 *$ & $-.05 * * *$ \\
\hline Couple with children & & & & & .03 & .00 \\
\hline Single parent & & & & & -.02 & -.02 \\
\hline Other & & & & & .02 & .03 \\
\hline Household income & & & & & $.08 * * *$ & .01 \\
\hline Region: East & & & & & $-.12 * * *$ & $-.11 * * *$ \\
\hline \multicolumn{7}{|l|}{ Variance components } \\
\hline Intercept (level 2) & 7.98 & 7.96 & 7.98 & 7.98 & 8.16 & 8.19 \\
\hline Residual variance (level 1) & 0.99 & 0.99 & 0.99 & 0.98 & 0.99 & 0.98 \\
\hline \multicolumn{7}{|l|}{ Model fit } \\
\hline Within-person $R^{2}$ & .00 & $.01 * * *$ & $.01 * * *$ & $.02 * * *$ & $.01 * * *$ & $.02 * * *$ \\
\hline Between-person $R^{2}$ & $.01 * * *$ & $.14 * * *$ & $.17 * * *$ & $.21 * * *$ & $.18 * * *$ & $.28 * * *$ \\
\hline
\end{tabular}


Table 3. Multilevel regression of life satisfaction on low labour income, financial strain and sense of control (random intercept models).

\begin{tabular}{|c|c|c|c|c|c|c|}
\hline & Model 1 & Model 2 & Model 3 & Model 4 & Model 5 & Model 6 \\
\hline & $b$ & $b$ & $b$ & $b$ & $b$ & $b$ \\
\hline \multicolumn{7}{|c|}{ Level 1 predictors (within persons) } \\
\hline Low labour income & $-.10 * * *$ & & $-.07 * * *$ & & $-.09 * * *$ & $-.07 * * *$ \\
\hline Financial strain & & $-.18 * * *$ & & $-.16 * * *$ & $-.18 * * *$ & $-.17 * * *$ \\
\hline Sense of control & & & $.15 * * *$ & $.14 * * *$ & & $.14 * * *$ \\
\hline \multicolumn{7}{|l|}{ Level 1 control variables } \\
\hline Age & & & & & $-.06 * * *$ & $-.06 * * *$ \\
\hline \multicolumn{7}{|l|}{ Occupational status } \\
\hline Non-manual employee & & & & & .00 & .00 \\
\hline Professional & & & & & .00 & .00 \\
\hline Hours per week & & & & & $-.01 * * *$ & $.02 * * *$ \\
\hline Job change: yes & & & & & $.01 * *$ & $.01 * *$ \\
\hline Temporary contract & & & & & $-.01 * * *$ & $-.01 * *$ \\
\hline \multicolumn{7}{|l|}{ Household type } \\
\hline Single & & & & & $-.28 * * *$ & $-.29 * * *$ \\
\hline Couple with children & & & & & $-.05 * * *$ & $-.06 * * *$ \\
\hline Single parent & & & & & $-.25 * * *$ & $-.26 * * *$ \\
\hline Other & & & & & $-.17 * * *$ & $-.17 * * *$ \\
\hline Household income & & & & & $.03 * * *$ & $.03 * * *$ \\
\hline \multicolumn{7}{|c|}{ Level 2 predictors (between persons) } \\
\hline Low labour income & $-.10 * * *$ & & $-.06 * * *$ & & $-.03 *$ & $-.02 *$ \\
\hline Financial strain & & $-.54 * * *$ & & $-.43 * * *$ & $-.46 * * *$ & $-.37 * * *$ \\
\hline Sense of control & & & $.44 * * *$ & $.27 * * *$ & & $24 * * *$ \\
\hline \multicolumn{7}{|l|}{ Level 2 control variables } \\
\hline Gender: woman & & & & & .00 & .02 \\
\hline Age & & & & & $-.15 * * *$ & $-.12 * * *$ \\
\hline \multicolumn{7}{|l|}{ Education } \\
\hline Vocational & & & & & $-.04 * *$ & $-.03 * *$ \\
\hline Tertiary & & & & & $.05 * * *$ & $.03 * *$ \\
\hline \multicolumn{7}{|l|}{ Occupational status } \\
\hline Non-manual employee & & & & & .00 & .01 \\
\hline Professional & & & & & $.04 * *$ & .01 \\
\hline Hours per week & & & & & $-.08 * * *$ & $-.09 * * *$ \\
\hline Job change: yes & & & & & $-.05 * * *$ & $-.06 * * *$ \\
\hline Temporary contract: yes & & & & & $-.03 *$ & $-.03 *$ \\
\hline Unemployment exp. & & & & & $-.08 * * *$ & $-.07 * * *$ \\
\hline Household income & & & & & $.29 * * *$ & $.23 * * *$ \\
\hline \multicolumn{7}{|l|}{ Household type } \\
\hline Single & & & & & $-.07 * * *$ & $-.07 * * *$ \\
\hline Couple with children & & & & & $.07 * * *$ & $.06 * * *$ \\
\hline Single parent & & & & & -.01 & -.01 \\
\hline Other & & & & & .01 & .02 \\
\hline Region: East & & & & & $-.24 * * *$ & $-.25 * * *$ \\
\hline \multicolumn{7}{|l|}{ Variance components } \\
\hline Intercept (level 2) & 6.46 & 6.45 & 6.47 & 6.45 & 6.70 & 6.72 \\
\hline Residual variance (level 1) & 0.99 & 0.97 & 0.98 & 0.95 & 0.96 & 0.97 \\
\hline \multicolumn{7}{|l|}{ Model fit } \\
\hline Within-person $R^{2}$ & .00 & $.03 * * *$ & $.02 * * *$ & $.05 * * *$ & $.04 * * *$ & $.06 * *$ \\
\hline Between-person $R^{2}$ & $.01 * * *$ & $.29 * * *$ & $.20 * * *$ & $.35 * * *$ & $.35 * * *$ & $.40 * * *$ \\
\hline
\end{tabular}


Table 4. Indirect effects of low labour income and financial strain, respectively, on mental health and life satisfaction via sense of control (overview of different models).

\begin{tabular}{|c|c|c|c|c|c|c|c|}
\hline & \multicolumn{3}{|c|}{ Mental health } & \multicolumn{4}{|c|}{ Life satisfaction } \\
\hline & $b$ SoC & $\begin{array}{l}\text { Indirect } \\
\text { effect }\end{array}$ & $95 \%$-CI & $b \mathrm{SoC}$ & $\begin{array}{c}\text { Indirect } \\
\text { effect }\end{array}$ & \multicolumn{2}{|c|}{$95 \%-\mathrm{CI}$} \\
\hline \multicolumn{8}{|l|}{ Level 1 (within persons) } \\
\hline Model 3: Low labour income & $-.09 * * *$ & $-.12 * * *$ & $-.16 ; \quad-.08$ & $-.09 * * *$ & $-.03 * * *$ & -.04 & -.02 \\
\hline Model 6: Low labour income with covariates & $-.06 * *$ & $-.07 * *$ & $-.16 ; \quad-.08$ & $-.06 * *$ & $-.02 * *$ & -.03 & -.01 \\
\hline Model 4: Financial strain & $-.11 * * *$ & $-.13 * * *$ & $-.15 ; \quad-.11$ & $-.11 * * *$ & $-.03 * * *$ & -.04 & -.02 \\
\hline Model 6: Financial strain with covariates & $-.10 * * *$ & $-.12 * * *$ & $-.16 ; \quad-.08$ & $-.10 * * *$ & $-.03 * * *$ & -.04 & -.03 \\
\hline \multicolumn{8}{|l|}{ Level 2 (between persons) } \\
\hline Model 3: Low labour income & $-.37 * * *$ & $-1.27 * * *$ & $-1.58 ;-.97$ & $-.37 * * *$ & $-.24 * * *$ & -.34 & -.19 \\
\hline Model 6: Low labour income with covariates & -.05 & -.15 & $-.42 ; \quad .12$ & -.07 & -.01 & -.06 & .01 \\
\hline Model 4: Financial strain & $-.65 * * *$ & $-1.69 * * *$ & $-1.82 ;-1.55$ & $-.65 * * *$ & $-.26 * * *$ & -.34 & -.19 \\
\hline Model 6: Financial strain with covariates & $-.63 * * *$ & $-1.83 * * *$ & $-1.58 ;-.97$ & $-.63 * * *$ & $-.23 * * *$ & -.25 & -.21 \\
\hline
\end{tabular}

Note. $N=7,107$. Random intercept models with fixed effects. Unstandardized coefficients from regression models presented in

Table 2 and 3, respectively. SoC Coef. $=$ Regression coefficient predicting sense of control. ${ }^{*} p<.05, * * p<.01, * * * p<.001$. 